https://helda.helsinki.fi

\title{
Vieläkö on syytä pohtia -sti-suffiksin olemusta?
}

\section{Jääskeläinen, Anni}

2020-12-18

Jääskeläinen , A 2020 , ' Vieläkö on syytä pohtia -sti-suffiksin olemusta? ' , Virittäjä , Vuosikerta. 124 , Nro 4 , Sivut 555-573 . https://doi.org/10.23982/vir.84773

http://hdl.handle.net/10138/339474

https://doi.org/10.23982/vir.84773

acceptedVersion

Downloaded from Helda, University of Helsinki institutional repository.

This is an electronic reprint of the original article.

This reprint may differ from the original in pagination and typographic detail.

Please cite the original version. 
Katsaus: Vieläkö on syytä pohtia -sti-suffiksin olemusta?

Anni Jääskeläinen

1. Johdanto

Risto Tuomikoski esitti vuonna 1973 artikkelissaan "Adjektiivin ja adverbin erosta", että -sti-suffiksi voidaan katsoa adjektiivien sijapäätteeksi ja että sen produktiivisesti tuottama muoto kuuluu näin ollen adjektiivien sijataivutukseen. Sijamuotoja olisivat myös adverbiaaleina toimivat, $n$ - ja inmuodot, joita Tuomikoski kutsuu -sti-muodon ohella "instruktiivisiksi". Nämä muodot on niin ikään monesti katsottu adverbeiksi eikä adjektiivinmuodoiksi. Esimerkkeinä muodoista Tuomikoski antaa muun muassa seuraavat: telepaattisesti aikaan saatuja aistimuksia, yrittäessään tieteellisesti osoittaa, vaikuttavat tehokkaimmin ja nopeimmin, pohjattoman hauskaa pilkkaa, loistavan havainnollisesti ja riemukkaan herjaavasti kuvattu. Tuomikosken päätelmä -sti-suffiksin olemuksesta ja tehtävästä kuuluu:

"Instruktiiviset" adjektiiviesiintymät käsittävät adjektiivivartalon lisäksi päätteen, joka voidaan lukea sijapäätteeksi. Myös sti on sijapääte sikäli että se sijapäätteiden tapaan on sellainen suffiksi, joka osoittaa saneen lauseenjäsenaseman (funktion), ts. se on relaattori (funktori, funktionaali). (Tuomikoski 1973: 204.)

Tuomikosken esitys on looginen ja hyvin perusteltu. Kuitenkaan se ei ole lopultakaan saanut kannatusta: vaikka idea -sti-suffiksin sijamaisuudesta on otettu huomioon ainakin maininnan verran (mm. Hakulinen \& Karlsson 1979: 85, 136; Itkonen 1986; Leino 1989: 173 alaviite; ISK $2004 \S 373$ ), ajatus -sti-suffiksin statuksesta sijatunnuksena jää lähinnä kuriositeetiksi. Se, että adjektiiveja ja adverbiaaleja määrittävät $n$-muodot (esim. pohjattoman hauskaa pilkkaa; loistavan havainnollisesti) ovat ainakin osittain adjektiivien produktiiveja sijamuotoja, on ollut helpompi hyväksyä (esim. Orpana 1988: 61; Jaakola 2004: mm. 201-202) kuin se, että -sti-muodot olisivat samoin sijamuotoja. Esimerkiksi Iso suomen kielioppi (ISK) kutsuu edelleen myös produktiivisesti tuotettuja -sti-muotoja adverbeiksi ja pitää sijojen määrän totunnaisessa 15:ssä, vaikka toteaakin -sti-muotojen sijoittuvan sijataivutuksen ja johtamisen väliselle harmaalle alueelle (ISK 2004 §2, § 1265).

Tässä katsauksessa palaan vielä Tuomikosken (1973) ajatukseen ja käyn läpi seuraavia kysymyksiä: Mitä eri tutkijat ovat todenneet -sti-suffiksista? Millä tavoin -sti-suffiksin olemus on mahdollista ymmärtää: mikä muodossa on sijamaista ja mikä ei? Entä miksi Tuomikosken (1973) 
ajatus -sti-suffiksista sijapäätteenä ei lopulta ole saanut kannatusta? Ja vielä: onko mahdollista lopulta sanoa, mikä -sti-suffiksi todella on ja mikä on se muoto, jonka se tuottaa?

\section{Lyhyesti -sti-suffiksin käytöstä ja merkityksestä}

Aloitan kuvaamalla lyhyesti -sti-suffiksia. $-s t i$ on produktiivinen ja varsin frekventti suffiksi, jonka esiintyvyys suomen kielisessä tekstissä vaihtelee Kielipankin aineistoissa 0,67 \%:sta (sanomalehtitekstit) 0,79\%:iin (Suomi24-korpus) ja 0,84\%:iin (kaunokirjallisuus). Vertailun vuoksi esimerkiksi eräiden vähän käytettyjen sijojen esiintyvyys on $0,2 \%$ (abessiivi), 0,1\% (komitatiivi) ja 0,3-2,0\% (instruktiivi, riippuen leksikaalistuneiden muotojen annotoinnista) (ISK $2004 \S 1227$ ). ${ }^{1}$ Osa muodoista, joissa on -sti, on selvästi leksikaalistuneita adverbeja (esim. niukasti, monesti, leikisti, tietysti, valitettavasti), kuten mm. Tuomikoski (1973) ja Orpana (1988) toteavat, mutta suurta osaa voidaan pitää produktiivisesti tuotettuina.

Yhdistyessään adjektiiveihin ja eräisiin voimasanasubstantiiveihin -sti tuottaa muotoja, joiden usein todetaan kuvaavan tapaa, määrää tai intensiteettiä tai ilmaisevan puhujan kommenttia (Orpana 1988; ISK 2004 § 373). "Tapa” on merkityskategoriana yläkäsitteen omainen: -sti-muodon tarkempi merkitys ja merkityksen tulkinta ovat hyvin kontekstisidonnaisia. Siihen vaikuttavat -stisuffiksin kantana olevan adjektiivin merkitys ja esimerkiksi lauseen verbi kehyksineen sekä muut lauseen pääjäsenet (ks. Orpana 1988: 77-118; myös Jääskeläinen \& Hamunen 2011). -sti-muotojen merkityksen kirjo on huomattavan laaja, ja -sti-muodon kantana oleva adjektiivi saattaa tosiasiassa

\footnotetext{
${ }^{1}$ Luvut perustuvat tekeillä olevaan artikkeliini "The Finnish -sti forms: derivation or case inflection?" teoksessa Jaakola, Minna \& Tiina Onikki-Rantajääskö (toim.), Cognitive linguistic perspectives on Finnish case system. Virittäjän nimetön arvioija kysyi, voiko ISK:n esittämää aineistoa ja Kielipankin aineistoa verrata keskenään. Tekstilajien puolesta ISK:n käyttämä aineisto (2004 § 1227) koostuu yleiskielisestä tekstistä, jossa on mukana proosaa yhden romaanin ja yhden näytelmän verran (Lauseopin arkisto) sekä sanomalehtiaineistosta, jossa on mukana yksi tietokirja (Parole). Tekstilajien puolesta aineistoja voi melko hyvin verrata (Suomi24-aineistoa vastaavaa aineistoa ISK:n laskuissa ei ole). ISK (2004 § 1227) ei kerro, minkä kokoisia laskennassa käytetyt korpukset ovat kokonaissanemäärältään. Sijamuodoissa olevien sanojen määrät ovat 130921 (Lauseopin arkisto) ja 158655 (Parole). Käyttämieni Kielipankin Suomen kielen tekstikokoelman sanomalehtiaineiston koko on 144117021 sanetta, kaunokirjallisuusaineiston (Kustannusosakeyhtiö Otava 1993) 37958 sanetta ja Suomi24-korpuksen 2663114497 sanetta. Kooltaan aineistot eivät vastaa toisiaan. Nähdäkseni tässä aineistojen vertailtavuuteen vaikuttaa kuitenkin enemmän tekstilaji kuin korpuksen koko; sijamuotojen määrät tuskin muuttuisivat oleellisesti, vaikka ISK:n laskuissa olisi käytetty isompaa aineistoa.
} 
luonnehtia tapauksesta riippuen montaa eri elementtiä lauseenytimessä (ks. Orpana 1988: 77-118). Lisäksi yhdistyessään numeraaleihin ja eräisiin pronomineihin (usea, moni) -sti tuottaa multiplikatiivisen merkityksen ('kuinka monta kertaa'). -sti-muotoja on tutkittu erityisesti merkityksen kannalta (Orpana 1988), mutta niiden syntaktinen kuvaus on jäänyt jonkin verran sivuun. Esimerkiksi Huumo (1997), joka tutkii eräitä muita adverbiaaleja semanttis-syntaktisesti, ei ota kantaa -sti-muotoihin tai muihin tavanilmauksiin. -sti-muodoissa on siis vielä paljon selvittämistä, ja tässä katsauksessa pohdinkin lähinnä yhtä lankaa vyyhdessä: sitä, minkälainen suffiksi -sti on morfologian ja sijamaisuuden kannalta.

Kuitenkin tutkittuani -sti-muotoja useammasta suunnasta (mm. Jääskeläinen ja Hamunen 2011, Jääskeläinen 2018) minun on helppo hyväksyä Tuomikosken (1973: 204) muotoilu: -sti-suffiksi tosiaankin toimii samaan tapaan kuin sijapäätteet osoittaessaan sananmuodon lauseenjäsenaseman; on tosin huomautettava, että kaikki sijat eivät kaikissa asemissaan toimi tietenkään pelkästään näin vaan tuovat mukanaan myös muunlaista merkityslisää. (Esimerkiksi partitiivi ilmaisee mm. toiminnan irresultatiivisuutta tai määrän indefiniittisyyttä: Söin omenan vs. Söin omenaa.)

Tuomikosken (1973) luonnehdinta -sti-morfeemista "funktionaalina" vastaakin sitä, miten Siro (1964) ja laajentaen Pentti Leino (1989: 182-189) sekä myöhemmin J. Leino (2003, mm. mts. 81) ovat kuvanneet sijapäätteiden tehtävää. Suffiksi -sti on "funktionaali" (Pentti Leino 1989 käyttää termiä "sijapredikaatti"), joka osoittaa kantasanansa suhteen korrelaattiinsa (käsitteet Sirolta 1964). Jos käytetään Siron (1964) termistöä, -sti-morfeemin korrelaattina on katsantotavasta riippuen joko lause tai lauseenydin (verbi täydennyksineen, esim. jakso Aurinko paistaa lauseessa Aurinko paistaa kaunii-sti) tai adjektiivi/adverbi tms., jota -sti-muoto määrittää etumääritteenä (esim. maisemallisesti arvokas).

Siron (1964) tarkastelu lähtee fennistiikassa poikkeuksellisesti morfeemeista käsin. Hän jakaa sijat ja adpositiot syntaktisen käytön perusteella kvasipredikaatteihin (myös Siro 1949: 39) ja "muihin funktionaaleihin" (myös kvasipredikaatit ovat eräitä funktionaaleja). Käsitteen taustalla on Martinet'n teoria (Siro 1964: 57). Siron kvasipredikaatti (1964: 25-29) ilmaisee kantanaan olevan sanan suhdetta lauseen toiseen sanaan. Esimerkiksi lauseessa Ruoka on pöydä-llä ilmaisee adessiivin sijapääte -llä tietynlaisen suhteen sanojen ruoka ja pöytä välillä (esimerkki mts. 26). Sen sijaan "muu funktionaali" ilmaisee Siron mukaan sanan suhdetta lauseen muuhun osaan mutta ei viittaa tiettyyn lauseenjäseneen. Näin ollen lauseessa Jäsen taipuu nivele-stä olisi elatiivi muu funktionaali, ja lauseessa Miksi häntä pitäisi viha-lla ajatella? olisi adessiivi puolestaan tapaa ilmaiseva muu funktionaali (esimerkit mts. 58 ja 63). Voidaan nähdä, että -sti-suffiksi toimii itse asiassa aivan samoin kuin Siro (1964: 57-64) kuvaa näiden eräiden "muiden funktionaalien" toimintaa. Siro itse ei 
kuitenkaan huomioi tätä yhteyttä, vaan lukee -sti-muodot adverbijohdoksina melko yksiselitteisesti leksikaalisiksi adverbeiksi (Siro 1964: 46). Pentti Leino (1989) toteaa Siron (1964) kuvauksesta, että eroa kvasipredikaattien ja muiden funktionaalien välillä ei tarvitse kognitiivisen kieliopin mukaisessa kuvauksessa tehdä, koska "kognitiivisessa kieliopissa sijapredikaatin muuttujana voi olla myös relationaalinen ilmaus"; tällainen juuri on esimerkiksi lause miksi häntä pitäisi ajatella, johon adessiivi -lla luo kantanaan olevalle nominille viha tietyn suhteen. Leino käyttää kantasanasta ja korrelaatista kognitiivisen kieliopin mukaisia termejä kiintopiste ja muuttuja (Pentti Leino 1989: 184). Sekä Tuomikosken että Pentti Leinon kuvauksessa morfeemi -sti osoittaa siis tietynlaisen suhteen kantanaan toimivan entiteetin ja toisen entiteetin välille, kuten sijapäätteet. ${ }^{2}$ Syntaktisesti -sti-muoto on lauseessa tai lausekkeessa adverbiaali.

Kaikkein skemaattisimmillaan morfeemi -sti on mahdollista nähdä syntaktisena merkitsimenä, joka ilmaisee, että adjektiivisanan kuvaama laatu kiinnitetään relaation (joko verbin kuvaamaan prosessin tai adjektiivin/adverbiaalin kuvaaman ei-temporaalisen relaation), ei olion, ominaisuudeksi (ks. Pentti Leino 1989: 173 alaviitettä; käsitteistä Langacker 2008: 98-100). Adjektiivi laadun kuvauksena lauseessa sidostuu usein semanttisesti tästä huolimatta pääsääntöisesti parhaaseen vastinpariinsa, kuten voidaan havaita, kun luetaan tarkasti Orpanan (1988) -sti-tutkimusta. ${ }^{3}$

Olen aikaisemmin kutsunut -sti-suffiksia tämän tehtävänsä mukaisesti nimityksellä "adverbializer" (Jääskeläinen \& Hamunen 2011). Nimitys itse asiassa ei ota kantaa siihen millainen suffiksi on kyseessä. Kyseessä olisi siis suffiksi, joka "adverbiaalistaa" adjektiivin, jolloin sitä on mahdollista käyttää kuvaamaan esimerkiksi verbiprosessin laatua, mutta ei välttämättä "adverbista" sitä eli tee siitä leksikaalista adverbia. Kuvasimme tätä -sti-morfeemin tehtävää kognitiivisen kielentutkimuksen viitekehyksessä valenssin kannalta: -sti luo kantanaan olevalle adjektiiville valenssin, paikan lauseessa tai lausekkeessa, jossa puolestaan on elaboraatiopaikka, jota -sti-muoto sopii työstämään (Jääskeläinen \& Hamunen 2011; ks. samanlaisesta kuvauksesta Hamunen 2019: 4445). ${ }^{4}$

\footnotetext{
${ }^{2}$ Entiteetti on kognitiivisessa kieliopissa yhteisnimitys kaikille konseptuaalisen rakenteen kuvauksessa tarvittaville käsitteille, mukaan lukien oliot ja relaatiot (Langacker 2008: 98).

${ }^{3}$ Käsittelen näitä kysymyksiä perusteellisemmin tekeillä olevissa kirjoituksissa "The Finnish -sti forms: derivation or case inflection?" sekä "Adjektiivien polysemiaa lauseissa: miten lauseenjäsenasema vaikuttaa tiheyden adjektiivien merkitysten ilmenemiseen?".

4 Valenssi on siis kaksisuuntainen. Voidaan ajatella, että esimerkiksi lauseessa Hän laulaa on elaboraatiopaikka tavanilmaukselle, tässä tapauksessa valinnaiselle adverbiaalille eli adjunktille (ks. Hamunen
} 


\section{Aiempaa tutkimusta -sti-suffiksista ja adverbeista}

Teen seuraavaksi katsauksen siihen, miten -sti-muotoja on aiemmin kuvattu. -sti-muotoja on fennistisessä tutkimuksessa käsitelty kolmelta kannalta. Ensinnäkin -sti-muodot on voitu katsoa leksikaalisen derivaation tulokseksi, eli johdetuiksi sanoiksi, jotka kuuluvat sanoina adverbien sanaluokkaan. Tällöin suffiksi $-s t i$ on yksiselitteisesti adverbijohdin. Tätä kantaa edustavat vanhemmat kieliopit ja monet uudemmatkin yleis- ja koulukieliopit, joiden tarkoitukseen asian problematisointi sopisi melko huonosti (esim. Setälä, Nieminen \& Ojajärvi 1974 [1964]: 166; Penttilä 1957: 324; Karlsson 1999: 218; Pirkko Leino 1999: 99-101; Alho \& Kauppinen 2008: 37).

Toiseksi sti-muodot voidaan katsoa syntaktisen derivaation tulokseksi: -sti-muodon saa aikaan adjektiivin asema lauseessa adverbiaalina. Tieteen termipankki antaa syntaktiselle derivaatiolle kuvauksen "sananjohto, jossa johdokset muodostetaan automaattisesti puhetilanteessa lauseyhteyden vaatimusten mukaisesti”. (Tieteen termipankki 23.07.2019: Kielitiede:syntaktinen derivaatio.) Tämän kannan -sti-muotoihin ottanee Sulkala (1981) ja eksplisiittisemmin Orpana (1988). Suomen produktiivisen johdosmorfologian kontekstissa näkemys on luonteva. -sti-muoto voidaan nähdä seurauksena lausekontekstin vaatimuksesta adjektiiville, ja se olisi syntaktisen aseman laukaisema. Erona leksikaalisiin adverbeihin olisi se, että syntaktisen derivaation tuloksena -stimuoto voitaisiin nähdä väliaikaisena muodosteena, sananmuotona, ei lekseeminä. ${ }^{5}$

2019: 45-47). Adjektiivi kaunis ei voi elaboroida tuota paikkaa, mutta kun se kombinoituu -sti-suffiksin kanssa (jonka oma valenssi mahdollistaa tämän kombinoitumisen), tuotetulla kompositiorakenteella kauniisti on sopiva valenssi. Sillä on nyt elaboraatiopaikka skemaattiselle muuttujalle, jota lauseen edustama relaatio puolestaan sopii elaboroimaan. (Ks. Pentti Leino 1993: 91-100; Langacker 2008: 198-205.)

${ }^{5}$ Suomen kielen tutkimuksessa osa johtamisesta on luontevaa nähdä syntaktisena, eli kyseessä ei ole varsinaisesti sanojen tuottaminen vaan lausekonstruktioiden vaatimuksiin vastaaminen. Kuitenkin taipumisen ja johtamisen ja toisaalta leksikaalisen ja syntaktisen johtamisen eronteko on hankala myös typologisesti ja se voidaan nähdä jatkumomaisena (yhteenvetoa esim. Portero Muños \& García Velasco 2018: 95-96). Typologiassa esimerkiksi Haspelmath (1996) on nähnyt syntaktisen derivaation idean ongelmalliseksi ja kritisoi termiä. Näen ongelman lähinnä terminologisena (johtamisen ajatellaan liittyvän tiukasti leksikkoon ja olevan vajaasti produktiivista) ja Haspelmathin (1996) esittämän kritiikin siltä kannalta, että terminä "syntaktinen derivaatio" ei Haspelmathin (1996) katsannossa kerro juuri muusta kuin muotojen tuottamisen vaivattomuudesta ja automaattisuudesta, minkä ominaisuuden Haspelmath (1996) mieluummin liittää fleksioon. Haspelmath (1996) ehdottaa syntaktisen derivaation sijaan termiä "sanaluokkaa vaihtava fleksio": 
Kolmanneksi -sti-muodot on nähty sijataipumisen tulokseksi. Tällöin -sti-muoto on yksi muoto adjektiivien sijaparadigmassa. Tämän näkemyksen mukaan suffiksi -sti toimii kuten muutkin sijatunnukset ja toissijaista on esimerkiksi se, että substantiiveilla ei pääasiassa ole -sti-muotoja. Myös muut -sti-sijan "puutteet", kuten lukuopposition puuttuminen, ovat tässä katsantokannassa selitettävissä, mihin palaan jaksossa 4. Tätä näkemystä edustaa Tuomikoski (1973), jonka kanta on jo esitelty: produktiiviset -sti-muodot eivät ole adverbeja vaan adjektiivin muotoparadigmaan kuuluvia sijamuotoja. Hakulinen ja Karlsson (1979: 85, 136) näkevät -sti-muodot Tuomikosken (1973) tapaan adjektiivinmuodoiksi, vaikka eivät eksplisiittisesti kutsu niitä sijamuodoiksi. ${ }^{6}$

Tarkastelen seuraavaksi Tuomikosken (1973), Sulkalan (1981) ja Orpanan (1988) näkemyksiä hieman tarkemmin.

Tuomikosken (1973) argumentointi lähtee siitä selviöstä, että kaikki adverbiaaleina (lauseenjäsenfunktio) toimivat muodot eivät suinkaan ole adverbeja (sanaluokka). Adverbiaaleina voidaan käyttää varsinaisten adverbien lisäksi myös esimerkiksi infinitiivimuotoja (esim. Hän juoksi kaatumatta, Hän juoksi linkaten), alisteisia lauseita (Hän juoksee niin että sininen savu sieraimista käy) ja produktiivisesti taivutettuja substantiivien sijamuotoja (Hän juoksi soratiellä, Hän juoksi junalle lapsineen, Hän juoksi kengittä). Vaikka nämä elementit siis toimivat adverbiaaleina, niitä ei tuossa asemassa suinkaan kutsuta "adverbeiksi". Adverbi on taipumattomien tai vajaasti taipuvien, adverbiaaleina käytettävien sanojen sanaluokka, ja esimerkiksi adverbiaaleina käytettäviä substantiivin sijamuotoja pidetään adverbeina vain, jos ne ovat kiteytyneitä. Tuomikoski (1973: 202) perää adverbeille yhtenäistä määritelmää:

fleksio kuvaa produktiivisuutta ja sanaluokan vaihtaminen sitä, että tällaiset elementit saavat uuden syntaktisen funktion lauseessa. Kuitenkaan myöskään Haspelmathin (1996) ehdotus ei suinkaan ratkaise -sti-muotojen ongelmaa: ensinnäkään ei ole varmaa, että -sti-muotojen sanaluokka olisi muu kuin adjektiivi ja toisekseen edelleen ongelmallinen on -sti-muotojen ja esimerkiksi adverbiaaleina käytettävien substantiivien sijamuotojen välinen ero. Jos Haspelmathia seurattaisiin, jouduttaisiin kutsumaan myös osaa substantiivien sijataivutuksesta "sanaluokkaa vaihtavaksi fleksioksi", jos sanaluokka määritellään lauseenjäsentehtävästä käsin.

${ }^{6}$ Nähdäkseni -sti-muotojen näkeminen adjektiivinmuotoina, joissa kantana olevan adjektiivin merkitys on sama kuin muilla sijamuodoilla, käy epäsuorasti ilmi myös esimerkiksi Nykysuomen sanakirjan (NS) artikkeleista. Eräät -sti-muodot ovat omina hakusanoinaan (esim. NS s.v. huonosti, pahasti), mutta suurin osa -sti-muodoista on adjektiivien sana-artikkelien esimerkkien joukossa, joissa -sti-muoto näyttäytyy yhtenä muotona muiden adjektiivinmuotojen joukossa (ks. esim. NS s.v. kankea, runsas, soma, sievä, tiheä). Kuitenkin NS kutsuu -sti-muotoja tradition mukaisesti adverbeiksi. 
Selvitettäessä adjektiivin ja adverbin rajaa koskevia perusteita on pyrittävä sellaisiin yleisiin perusteisiin, jotka yhtälaisesti soveltuvat myös substantiivin ja adverbin välisen rajan käyntiin. Tällainen peruste on tietenkin se, että adverbit ovat "taipumattomia", toisin kuin nominit. (Tuomikoski 1973: 202.)

Seuraa todisteluja, joiden jälkeen Tuomikoski (1973: 209) toteaa:

- - jos adverbin erottamiseen adjektiivin sijamuodosta käytetään samoja produktiivisuusperiaatteita kuin substantiivilähtöisen adverbin ja substantiivin rajankäyntiin, niin suomen "instruktiivisia" sti-, in- ja n-muotoja ei voida yleensä pitää adverbeina, vaan adjektiivin taivutukseen kuuluvina sijamuotoina. (Tuomikoski 1973: 209.)

Tuomikoski alleviivaa adverbikategorian yhtenäistä määrittelyä: vaikka osa adjektiivien -stimuodoista on selvästi kiteytyneitä ja leksikaalistuneita (siis adverbeja), kuitenkin suurin osa -stimuodoista on katsottavissa produktiivisesti tuotetuiksi. Kyseessä on adjektiivin ja suffiksin muodostama syntagma samaan tapaan kuin sijamuotoisissa sanoissa on kyse nominin ja sijapäätteen muodostamasta syntagmasta, jolloin kyseessä ei ole sellainen muoto, jota adverbilla yleensä tarkoitetaan. -sti-suffiksin Tuomikoski (1973) näkee siis samanlaiseksi kuin sijatunnuksen.

Tuomikosken (1973) vaikutusta lienee, että eräät muut tutkijat ovat luopuneet ajatuksesta, että -sti-muodot olisivat varsinaisesti (leksikaalisia) adverbeja. Kuitenkin näyttää siltä, että -sti-muotoa ei silti ajatella sijamuodoksi. Ajan adverbeja tutkiva Helena Sulkala (1981) ei pidä -sti-muotoja "varsinaisina" adverbeina ja kuvaa luokitteluaan seuraavasti:

Produktiivisilla johtimilla ( $s t i, \sin )$ muodostetut nominikantaiset sanat olen samoin luokitellut nomineihin, koska niiden transparenssi on selvä: niillä on tunnistettavissa oleva samamerkityksinen kantasana, ja johdoksen merkitys (esim. nopeasti, kahdesti, aamuisin) on sama kuin kantasanan ja johtimen merkityksen summa. (Sulkala 1981: 50.)

Sulkala määrittelee "varsinaisen" adverbin seuraavasti (Sulkala 1981: 51):

[varsinainen adverbi on sana] 1) joka ei taivu 2) joka ei ole samassa kielimuodossa esiintyvän nominin transparentti sijamuoto (esim. aamulla) 3) eikä samassa kielimuodossa esiintyvän nominin transparentti, syntaktisesti derivoitu johdos (esim. aamuisin) 4) joka ei saa attribuuttia ja 5) joka ei itsekään esiinny attribuuttina.

Nämä kriteerit jättävät selvästi -sti-muodot "varsinaisten" adverbien ulkopuolelle; ne rajaa ulkopuolelle joko ehto 2 tai 3, näkökulmasta riippuen. Sulkala (1981) jättääkin -sti-muodot kokonaan adverbien tarkastelunsa ulkopuolelle. 
Sulkalan (1981) tarkoitus ei ole ollut pohtia -sti-muotoja tarkemmin. Hän kuitenkin jakaa adverbikategorian "varsinaisiin" adverbeihin ja johonkin muuhun. Mutta mitä tuo muu on? Luen Sulkalan (1981: 50) muotoilun niin, että hän näkee -sti-muodot nominien muodoiksi eikä lainkaan adverbeiksi. Sijamuodoista hän ei kuitenkaan puhu.

Terttu Orpana (1988) on tutkinut adjektiivikantaisia adverbiaaleina käytettäviä muotoja ja myös ottanut kantaa sekä adverbisanaluokan määrittelyyn että -sti-muotojen olemukseen. Kuten Tuomikoski (1973) ja Sulkala (1981), Orpana toteaa, että osa -sti- ja - $n$-muodoista on leksikaalistuneita mutta osa selvästi produktiivisia ja transparentteja. Juuri näiden transparenttien muotojen asema on se, joka herättää kysymyksiä. Orpana (1988) kannattaa ajatusta syntaktisesta derivaatiosta. Hän kirjoittaa:

Adverbien luokan ydinkysymys on, missä määrin on oletettavissa erillinen sanaluokka, missä määrin produktiivinen semanttis-syntaktinen säännöstö, joka fleksion tai derivaation avulla tuottaa ilmauksia tiettyyn funktioon. (Orpana 1988: 57-58.)

Vaikka -sti-muodot voidaankin nähdä "adjektiivinmuodoiksi”, silti Orpanakaan (1988) ei sitoudu kutsumaan niitä adjektiivien sijamuodoiksi. Orpana (1988) kutsuu sekä leksikaalistuneita että produktiivisesti tuotettuja -sti-muotoja yhtä lailla adverbeiksi, koska näkee sanaluokan määrittelyn ennen kaikkea syntaktisena:

Adverbeista olisi puhuttava ainakin sikäli, että STI-johdin muuttaa adjektiivin syntaktisia ominaisuuksia, esim. kaunis laulu, Tyttö laulaa kauniisti. Muuttaessaan lekseemin syntaktista käyttöohjetta se muuttaa sanaluokkaa. Kyse on syntaktisesta derivaatiosta, jos kannan merkityksessä ei tapahdu mitään muutosta - - . (Orpana 1988: 60.)

Orpana ei siis näe ongelmallisena -sti-muotojen kutsumista adverbeiksi. (Kuitenkin toteamus "Kyse on syntaktisesta derivaatiosta, jos kannan merkityksessä ei tapahdu mitään muutosta" on epäselvä eihän esimerkiksi taivuttamisessa tapahdu tuollaista muutosta.) Silti on ilmeistä, että tämä ratkaisu ei vastaa Tuomikosken (1973) nostamaan ongelmaan: Kun näin tehdään, on kahdenlaisia adverbeja. Yhtäältä on sanaluokka, jonka määrää taipumattomuus ja kiteytyneisyys, ja toisaalta sanaluokka (?), jonka määrää vain syntaktinen käyttö. Jos adverbien sanaluokan tosiaan määräisi nimenomaan syntaktinen asema, silloinhan monia myös substantiivien produktiivisia sijamuotoja pitäisi kutsua adverbeiksi, samoin eräitä infinitiivimuotoja.

Syntaktista johtamista kannattavassa näkemyksessä -sti-muotojen asema saattaa jäädä hieman epäselväksi, sillä ne voidaan nähdä vaihtelevasti adverbeiksi tai sitten "adverbeiksi” - sanoiksi, jotka 
toimivat adverbiaaleina ja näyttävät adverbeilta mutta jotka eivät oletetun väliaikaisuutensa takia ole varsinaisesti sanoja vaan sananmuotoja (ks. eronteosta esim. Penttilä 1957: 115-118). Tätä Tuomikoski (1973) kritisoi: adverbi on kuitenkin sanaluokan nimi. Voiko sanaluokan jäsenyyden perustella yleensä vain saneen syntaktisella asemalla? Näinhän ei suomen kielen tutkimuksessa muuten tehdä esimerkiksi substantiivin sijamuotojen kohdalla, kun ne toimivat adverbiaaleina. Silloin -sti-muodot (ja adverbiaaleina toimivat adjektiivien - $n$ - ja -in-muodot) ovat erityistapaus, johon pätevät eri säännöt kuin muihin muotoihin, mitä Tuomikoski (1973) pitää huonona ratkaisuna.

\section{Miten hyvin -sti-muoto vastaa sijaa?}

Olen toisessa kirjoituksessa selvitellyt sitä, miten -sti sopii sijaksi ja millaisia kriteereitä sen sijamaisuuden puolesta ja sijamaisuutta vastaan on esitetty ja voidaan edelleen esittää. ${ }^{7}$-sti-muodon sijastatuksen puolesta on esitetty seuraavia seikkoja: -sti vastaa produktiivisuudeltaan sijamuotoa ja se säilyttää adjektiivin valenssin (ISK $2004 \S 62,1265$ ). -sti-tunnuksen sijainti sanan lopussa on sama kuin sijatunnuksen (ISK $2004 \S 62$ ). Vastaan on esitetty seuraavat seikat: -sti-muodoilla ei ole monikkoa (ISK $2004 \S 62,1265$ ), muodostus on produktiivista vain adjektiiveista (ISK $2004 \S 62$, 1265) ja muodostuksella on samantyyppisiä semanttisia rajoituksia kuin komparaatiolla (ISK $2004 \S$ 62). Lisäksi ISK (2004 § 1265) esittää sijamaisuutta vähentävä piirteenä sen, että "adjektiivi- ja pronominikantaisilla sti-sanoilla on myös komparaatiomuotoja: kauniimmin, useammin". Summaan tässä näitä kysymyksiä lyhyesti ja tarkastelen sen jälkeen -sti-muotojen morfologiaa tarkemmin.

Vahva sijamaisuutta vähentävä piirre on se, että -sti ei kiinnity produktiivisesti kaikkiin nomineihin, vaan ainoastaan adjektiiveihin ja voimasanasubstantiiveihin (esim. kauniisti, pahasti; pirusti, helvetisti). Lisäksi on muutama kvantifioiva pronomini (monesti, useasti) ja poikkeussubstantiivi, joihin se liittyy (mm. leikisti), joista jälkimmäisiä voi pitää leksikaalistumina. Tämä on selvä poikkeus muista sijoista. Esimerkiksi typologiassa sija määritellään monesti niin, että sijatunnus osoittaa nimenomaan substantiivin suhdetta verbiin tai muuhun pääsanaan (mm. Blake 1994: 1, jota määritelmää myös Word Atlas of Language Structures käyttää, ks. Iggesen 2013; ks. myös esim. Kittilä, Västi \& Ylikoski 2011). ${ }^{8}$

\footnotetext{
7 “The Finnish -sti forms: derivation or case inflection?” teoksessa Jaakola, Minna \& Tiina Onikki-Rantajääskö (toim.), Cognitive linguistic perspectives on Finnish case system.

${ }^{8}$ Blake (2001: 1) muotoilee: "Case is a system of marking dependent nouns for the type of relationship they bear to their heads. Traditionally the term refers to inflectional marking, and, typically, case marks the
} 
Substantiivi on tavallinen, jopa prototyyppinen, itsenäisessä lauseenjäsentehtävässä olevan lausekkeen (muun kuin VP:n) edussana, ja monesti juuri substantiivin sijataipuminen osoittaa lauseenjäsensuhteen. Suomen kielessä substantiivin etumääritteenä adjektiivi kongruoi pääsanansa kanssa, joka määrää sijamuodon ja numeruksen, eli adjektiivin sijataipuminen ei ole tällaisessa asemassa itsenäistä. Kuitenkin eräissä asemissaan adjektiivi ei kongruoi suoraan pääsanasubstantiivin kanssa: näin on, kun adjektiivi on itsenäisenä lausekkeena predikatiivina (esim. Hän on kaunis, Puuro tuli mustaa) tai esimerkiksi predikatiiviadverbiaalina (Hän on tänään kauniina, Hän muuttui kauniiksi; Hän muuttui sievästä kauniiksi). Lukukongruenssin määrää lauseen subjekti, mutta se ei kuitenkaan ole adjektiivin pääsana, vaan adjektiivin sijamuodon määrää joko verbin valenssi, esiintymiskonstruktio tai jokin semanttinen seikka. Näissä tapauksissa adjektiivilla on siis sijamuoto ilman että se olisi pääsanasubstantiivin kanssa kongruoiva määrite, jolloin ei voi sanoa, että sijamuoto näissä tapauksissa osoittaisi substantiivin suhdetta verbiin tai muuhun pääsanaan. (Adjektiivin sijamuoto ei kuitenkaan pelkästään osoita lauseenjäsenasemaa vaan tuo mukanaan merkityskontribuutiota.) Näiden esimerkkien jatkoksi sopii hyvin -sti-muodon käyttö adverbiaalina (esim. Hän laulaa kauniisti, Hän oli kauniisti 'käyttäytyi'); myös tämä on niitä käyttöjä, joissa adjektiivi on "vapaa" substantiivipääsanasta ja pääsanan määräämästä kongruenssista. -sti-muoto voidaan silti nähdä edelleen adjektiivin muotona, kuten essiivi (Hän on tänään kauniina) tai translatiivi (Hän muuttui kauniiksi).

Myös se, ovatko adjektiivit itse asiassa sanaluokka, on herättänyt kysymyksiä typologiassa. Suomessahan adjektiivit voitaisiin katsoa substantiivien alakategoriaksi sijataivutuksen vuoksi (Pajunen 1994: 531 ja siinä mainitut lähteet). Kuitenkin Pajunen (1994) on osoittanut, että suomen adjektiivit eivät ole substantiivien alaryhmä vaan oma erillinen sanaluokkansa. Nähdäkseni myös -stimuodon käyttäytyminen tukee osaltaan tätä näkemystä: -sti-morfeemin produktiivinen käyttö on yksi kohta, jossa suomen adjektiivit eroavat selvästi substantiiveista. Pajunen (1994) ei kuitenkaan tutkimuksessaan ota huomioon -sti-muotoja adjektiivinmuotoina vaan ilmeisesti laskee ne adverbeiksi (asiaa ei eksplisiittisesti mainita). Pajunen (1994: 537) kirjoittaa: "Aineistosta [adjektiivien ja substantiivien sijamuotojakaumista] voidaan päätellä, että adjektiiveilla ei ole sellaisia itsenäisiä semanttisia funktioita, joita suomessa osoitettaisiin suoraan tai välillisesti

relationship of a noun to a verb at the clause level or of a noun to a preposition, postposition or another noun at the phrase level." Myöhemmin Blake (2001: 7) tosin toteaa, että sijoja voivat saada myös ensinnäkin muut nominit (kuten pronominit) ja sanat "that are not obviously nouns". Esimerkkeinä Blake (mp.) antaa esim. kreikan adjektiivit (joita käytetään substantiivisesti) ja eräät adverbit. 
sijatunnuksin.” Jos Pajunen (1994) olisi laskenut -sti-muodot adjektiivinmuodoiksi, tässä kohtaa tulos olisi luultavasti erilainen: "tavanilmaiseminen" (yläkategoriana) olisi adjektiivien itsenäinen, sijatunnuksella ilmaistava funktio.

Toisaalta nimenomaan fennistiikassa (jo nominien ryhmän perustavan morfologisen määrittelyn vuoksi) "sija" ja "sijataipuminen" on määritelty niin, että se kattaisi helposti myös -stimuodot, sillä sijataipumisen yhteydessä puhutaan substantiivien sijaan nomineista. ISK:n määritelmä sijasta kuuluu:

SIJA on morfosyntaktinen ja morfosemanttinen kategoria, jonka tunnus on sijapääte. SIJAPÄÄTE ilmaisee, missä syntaktisessa ja semanttisessa suhteessa nominaalinen sana tai lauseke on muuhun lauseeseen. (ISK $2004 \S 1221$.)

Tieteen termipankki puolestaan muotoilee termin sija samaan tapaan (korostus lisätty):

[Sija on] taivutuskategoria, jonka edustajilla ilmaistaan nominilausekkeiden erilaisia syntaktisia ja semanttisia suhteita lausumassa. (Tieteen termipankki 23.7.2019: Kielitiede:sija.)

-sti-suffiksihan toimii juuri näin: se osoittaa, missä syntaktisessa ja semanttisessa suhteessa nominilauseke (adjektiivi, numeraali) on muuhun lauseeseen tai pääsanaansa. Näiden muotoilujen perusteella ei olisi syytä olla pitämättä -sti-muotoa sijana.

Sekoittaisiko -sti-muodon pitäminen sijana yhtenäistä sijojen kategoriaa? Tosiasiassa sijojen joukko on jo nyt epäyhtenäinen, mitä kuvaa myös sijojen jakaminen esimerkiksi kieliopillisiin, semanttisiin ja marginaalisiin tai vajaakäyttöisiin sijoihin. Eri sijamuotojen käyttötavat, yleisyys ja produktiivisuus ovat keskenään erilaisia. (Ks. Ylikosken artikkelia tässä Virittäjän numerossa.) Sijojen kategoria ei ole tällaisenaan kiveen hakattu: Välillä varsinkin akkusatiivin asemaa sijana on pohdittu. ${ }^{9}$ Toisaalta sijoiksi on joskus luettu myös eksessiivi (ks. Särkkä 1969), joka sopii sijojen joukkoon vaikka ei esiinny yleiskielessä. Erikseen on joskus puhuttu myös adverbisijoista, joilla tarkoitetaan niitä usein historiallisia ja monesti hyvin vajaasti produktiivisia muototyyppejä, joissa adverbista on erotettavissa jokin suffiksi, jolla on tunnistettava merkitys. Näiden muotojen

\footnotetext{
${ }^{9}$ Esim. ISK laskee akkusatiivisijaksi vain $t$-tunnuksella merkityt persoonamuodot (minut, sinut jne.). Sen sijaan objektina olevia genetiivi- ja nominatiivimuotoja ISK ei pidä akkusatiiveina. Perinteisesti, ja edelleen varsinkin typologisesti suuntautuvassa tutkimuksessa, myös jälkimmäiset lasketaan akkusatiiveiksi. Tällainen akkusatiivi on suomen sijana epätyypillinen: muodolla on monta ilmiasua ja sen määrää syntaktinen asema, ei vain morfologia.
} 
näkeminen sijoiksi (joskin vain adverbien sijoiksi) perustuu osittain myös sille, että eri kielistä saattaa löytyä produktiivinen sija, jolla on vastaava merkitys. Adverbisijoiksi on voitu lukea esimerkiksi nykysuomessa täysin epäproduktiivinen latiivi (esim. ylös, alas), osittain produktiivinen ja sijamainenkin prolatiivi (ylitse, maitse) ja eräitä muita muotoja (esim. ns. temporaali maanantaisin, kesäisin ja distributiivi maittain, metreittäin). Prolatiivin, temporaalin ja distributiivin asemasta ja sijamaisuudesta on viimeksi puhunut valaisevasti Ylikoski (2018 ja tässä numerossa).

Toisena sijamaisuutta vähentävänä piirteenä mainittiin lukuopposition puuttuminen: -stimuodoilla on vain yksikkömuotoja. Kuitenkin jo Tuomikoski (1973: 202) perustelee tämän ongelman oikeastaan näennäiseksi. Adjektiivin taipuminen luvussa on lukukongruenssin alainen ilmiö, jossa luvun määrää substantiivi (tai predikatiivin ja predikatiiviadverbiaalin tapauksessa joskus persoonan lukuoppositio). Silloin kun adjektiivi ei määritä substantiivia tai luonnehdi substantiivilla ilmaistua tarkoitetta tai monikollista persoonaa, sillä ei voikaan olla lukua. Tuomikoski kirjoittaa:

Ahlmanin [1933] mukaan "se, ettei adverbi kongruoi luvussa eikä sijassa määräämänsä sanan kanssa, erottaa sen adjektiivista”. Kongruenssin puute kuitenkin osoittaa vain sen, että kysymys ei ole substantiivin adjektiivisluonteisesta määritteestä. Sane, joka ei ole substantiivi eikä substantiivin kongruentti määrite, ei välttämättä ole juuri adverbi. - - Määrittäessään verbiä, adverbia tai toista adjektiivia adjektiivin muoto ei mitenkään voi sijaltaan ja luvultaan mukautua edussaneensa muotoon, sillä siinä tapauksessahan edussane olisikin substantiivi. (Tuomikoski 1973: 202.)

-sti-muodot esiintyvät siis sellaisessa syntaktisessa ja semanttisessa asemassa, ettei niillä edes voisi olla monikkoa. Laaduilla, joita adjektiivit kuvaavat, ei ole itsessään lukua. Luku on substantiivilla kuvattavien, jaottomien olioiden piirre. ${ }^{10}$ Kun siis adjektiivi esiintyy asemassa, jossa luku on irrelevantti semanttinen piirre, on aivan luontevaa, että se esiintyy tunnusmerkittömässä muodossa eli yksikössä. Lisäksi on mainittava sekin, että lukuoppositio ei esiinny täydellisenä kaikissa muissakaan sijoissa: komitatiivilla morfologisesti monikkomuotoisella muodolla ilmaistaan myös

\footnotetext{
${ }^{10}$ Luku on nominien taivutuksen lisäksi tietenkin myös persoonataivutuksen ilmiö. Niinpä predikatiivina oleva adjektiivi, jolla luonnehditaan myös persoonapronominilla tai persoonan taivutustunnuksella ilmaistua persoonaa, mukautuu persoonan lukuun: Olen varma, Olemme varmoja. Virittäjän nimetön arvioija kysyi, miten on sellaisten tapausten laita, joissa on passiivi, esim. Tästä asiasta ollaan varmoja. Suomen impersonaalinen ja henkilöviitteinen passiivi voidaan lukea yhdeksi persoonaksi. Predikatiivistakin nähdään, että persoonana passiivi mielletään monikolliseksi. (Vilkuna 1996: 139-40.)
} 
yksiköllistä merkitystä, ja instruktiivilla vain monikkomuoto on produktiivinen, kun taas instruktiivin yksikön esiintyminen on muutaman kiteytymän varassa.

Vielä -sti-muotojen sijamaisuutta vähentävänä produktiivisuuden rajoituksena ISK esittää, että -sti-muotojen muodostuksella on samantyyppisiä semanttisia rajoituksia kuin komparaatiolla (ISK $2004 \S 62$ ), eli kaikentyyppisistä adjektiiveista -sti-muoto ei ole luonteva (myös ISK $2004 \S$ 273). Tässä asia on liian laaja käsiteltäväksi, mutta esitän toisaalla ${ }^{11}$, että produktiivisuusrajoitukset eivät ole absoluuttisia vaan suhteellisia ja tietynlaisessa kontekstissa moni "mahdoton" muoto on mahdollinen. Adjektiivien käytettävyys -sti-muodossa liittyy adjektiivityyppeihin (esim. Dixon 2004) ja siihen, miten inherenttejä ja kiinteitä ominaisuuksia adjektiivit kuvaavat. Jos adjektiivin kuvaama laatu on kiinteästi olioon kuuluva, adjektiivi sopii huonommin määrittämään prosessia tai muuta relaatiota. Silloin, kun adjektiivin kuvaama laatu kuitenkin syntyy prosessin aikana tai sen seurauksena, myös muuten huonommin -sti-muodoiksi sopivat adjektiivit ovatkin mahdollisia. Esimerkkinä huonosti -sti-muodon saavista adjektiiveista ISK (2004 § 273) antaa muun muassa väriä ilmaisevat adjektiivit. Kuitenkin eräissä tapauksissa väri näyttää voivan olla -sti-muodossa, nimittäin sellaisissa tapauksissa, joissa väri ilmenee prosessissa tai syntyy sen tuloksena. Tällaisia tapauksia on esimerkiksi loistaminen:

\section{Polonium hohkaa pimeässä heikon sinisesti alfasäteilyn seurauksena (Internet 1).}

2. Talviaurinko on varmasti ihan oma persoonansa, välillä se paistaa himmeän keltaisesti, välillä viileän harmaana. (Internet 2)

Itse asiassa -sti-muotojen ja -sti-tunnuksen merkitys sopii hyvin sijojen joukkoon: myös monet sijoista kuvaavat adverbiaalisia merkityksiä, esimerkiksi tapaa, keinoa, välinettä, asentoa, jonkin kanssa tai ilman jotakin olemista ja niin edelleen. Lähimmäksi merkitykseltään ja myös lauseenjäsenasemaltaan tulee instruktiivi, joka kuvaa mm. välinettä, keinoa ja tapaa (ks. Leskinen 1990: 4-10; myös esim. Penttilä 1957: 439-443). Myös abessiivin ja komitatiivin merkitykset ja käyttö ovat osin samantyyppisiä kuin -sti-muodolla adverbiaalisuudessaan. Lisäksi -sti-muotojen rinnalla hyvin vastaavassa merkityksessä käytetään myös illatiivia ja partitiivia, joskin nämä esiintyvät enimmäkseen adverbistuneissa sanoissa (esim. Hän juoksee kovaa; Deep Purple in Rock soi aikoinaan levylautasella taajaa / taajasti / taajaan (alkuperäinen, korostettu lause Suomi24korpus). Myös adessiiviä käytetään tavan ilmaisuissa (esim. selvitä tentistä helpolla, Hän kuunteli

11 “The Finnish -sti forms: derivation or case inflection?” teoksessa Jaakola, Minna \& Tiina OnikkiRantajääskö (toim.), Cognitive linguistic perspectives on Finnish case system. 
hartaudella, vrt. selvitä tentistä helposti, Hän kuunteli hartaasti). ${ }^{12}$ Lisäksi -sti-muoto on essiiville eräissä käytöissään lähes synonyyminen (esim. Vaari mutristi harmistuneesti/harmistuneena suutaan) (ks. Orpana 1988: 88-89; esimerkki Orpana 1988: 89).

Se ISK:n antama (2004 § 1265, myös § 301; vrt. kuitenkin § 375) -sti-muotojen sijamaisuutta vähentävä kriteeri, että "adjektiivi- ja pronominikantaisilla sti-sanoilla on myös komparaatiomuotoja: kauniimmin, useammin" on yksinkertaisesti virhemuotoilu: -sti-muodoilla ei suinkaan ole tällaisia komparaatiomuotoja, vaan -sti-muodot muodostavat näiden komparatiivi- ja superlatiivimuotojen kanssa semanttisen vertailuparadigman, jossa -sti-muoto toimii perusasteena. Tämä vertailuparadigma on morfologisesti sekaparadigma. Muodot kauniimmin, useammin eivät ole -stimuotojen muotoja vaan komparatiivisuffiksillisten adjektiivien monikon instruktiivimuotoja (esim. Tuomikoski 1973); niiden rinnalla voidaan käyttää samoista vartaloista tehtyjä -sti-muotoja (kauniimma-sti, usea-mma-sti), mikä itse asiassa lisää -sti-muodon sijamaisuutta (tarkemmin alla). ${ }^{13}$

Vahvimmin -sti-suffiksin sijamaisuus tuleekin esille morfotaksin kannalta. Morfotaktisesti -stisuffiksi vastaa sijatunnusta: se kiinnittyy nominin taivutusvartaloon sijatunnuksen paikalle (johdinsuffiksien jälkeen) ja sen perään voi sananmuotoon kiinnittyä liitepartikkeleita (-kin, - hAn jne.). Sen luonnetta nimenomaan sijatunnuksena eikä johtimena todistaa varsinkin kaksi morfotaktista piirrettä: komparaatiovartaloihin liittyminen (esim. että tulisin helpommasti raskaaksi) ja lukusanojen taivuttaminen (esim. yhdestitoista).

Ensinnäkin se, miten -sti-tunnus liittyy komparatiivi- ja superlatiivimuotoisiin adjektiiveihin, kertoo paljon tunnuksen olemuksesta. Adjektiivien komparaatiomuodot ovat selvästi johdoksia, sillä ne taipuvat edelleen kaikissa sijamuodoissa, yksikössä ja monikossa (esim. helpo-mpi, helpo-in helpo-mma-ssa, helpo-imma-ssa, helpo-mm-i-ssa; helpo-imm-i-ssa). Myös -sti voi liittyä samaan tapaan adjektiivien komparaatiovartaloon, eli se toimii kuin sijatunnus:

3. minulla on liian vähän keltarauhas hormoonia niin tämä lääke lisää sitä että tulisin helpommasti raskaaksi. (Internet 3)

\footnotetext{
${ }^{12}$ Perinteisesti kielenhuolto on vieroksunut osaa tällaisesta käytöstä svetisistisenä (esim. Penttilä 1957: 421422). Nykyisin tapaa ilmaisevat adessiivit hyväksytään myös yleiskielessä (Korhonen \& Maamies 2015: 141). ${ }^{13}$ Virittäjän nimetön arvioija kysyi -(i)ten-muodoista (esim. nopeiten, parhaiten) (esim. ISK $2004 \S 376$ ). Nämä epäproduktiiviset muodot, joita esiintyy vain harvoista lekseemeistä, ovat enimmäkseen tuoreita analogisia muodosteita (Pulkkinen 1994). Muutama lekseemi on kuitenkin yleisempi -(i)ten kuin -imminmuodossa (eniten, pahiten). Pulkkisen (1994) mukaan syynä lienee se, että paljonkäytettyjen sanojen komparatiivi- ja superlatiivimuotojen eroa on haluttu selventää (komparatiivi pahemmin vs. superlatiivi pahimmin/pahiten).
} 


\section{4. [en] osaa tehdä yhtä vaivaista banneria maailman helpoimmasti opastetulla ohjelmalla.} (Internet 4)

Tällaisia -sti-muotoisia komparatiiveja on pidetty murteellisina tai muuten marginaalisina (Tuomikoski 1973: 208; ISK 2004 § 373). Niiden sijaan käytetäänkin varsinkin yleiskielessä sellaisia komparaatiomuotoja, joissa komparaatiosuffiksin jälkeen tulee toinen sijatunnus, nimittäin monikon instruktiivin tunnus (esim. helpo-mm-in, helpo-imm-in). Mitenkään mahdottomia komparaatiomuotojen -sti-muodot eivät silti ole: Korp-hakutyökalulla löytyy Suomi24-korpuksesta (koko 2663114497 sanetta) 4231 tapausta, jossa -sti liittyy komparaatiovartaloon (lukuun on etsitty vain esiintymät ilman liitepartikkeleja, eli todellinen määrä on hieman suurempi). Kielipankin yleiskielisessä Lehdet-aineistossa (koko 144117021 sanetta) näitä muotoja on 56 (ilman liitepartikkelillisia muotoja). ${ }^{14}$

Adverbiaaleina käytettävät vertailumuodot (positiivi, komparatiivi, superlatiivi) muodostavat sekaparadigman, jossa $-s t i$ on itse asiassa toisen sijan, monikon instruktiivin positionaalinen allomorfi; merkityksen puolestahan -sti-muoto ja instruktiivi ovat läheisiä. - Kielenkäyttäjille komparaatiojohtimista ja kahdesta eri sijatunnuksesta rakentuva adverbiaaleina käytettävien muotojen vertailuparadigma lienee morfologisesti läpinäkymätön, mutta se ei poista sitä tosiasiaa, että se on morfologisesti sekaparadigma. -sti-muodon asemaa sijana puoltaa siis kaksi piirrettä komparaatiomuodoissa: liittyminen adjektiivien komparaatiovartaloon kuten muut sijatunnukset ja adverbiaaleina käytettävien vertailumuotojen muotoparadigmassa paikan jakaminen toisen sijatunnuksen kanssa.

Toiseksi myös -sti-muodon liittyminen yhdyssanamuotoisiin numeraaleihin on samanlaista kuin muiden sijatunnusten: tunnus liitetään numeraalin taipuvaan osaan (esim. kolme-ssa-toista, kolme-sti-toista). On väitetty, että yhdyssanasubstantiivit eivät taipuisi -sti-muodossa (ISK $2004 \S$ 374), mutta väite on yksinkertaistus. Ilmaisutarpeen niin vaatiessa myös luvut 10:stä eteenpäin voivat taipua -sti-muodossa - on tietenkin tavallisempaa, että jotakin tapahtuu kahdesti tai kolmesti kuin että jotakin tapahtuu lasketusti seitsemästitoista. Silloin kun ilmaisutarve on ja -sti-muotoista numeraalia käytetään, nähdään, että -sti-tunnus sijoittuu sijatunnuksen paikalle:

\footnotetext{
${ }^{14}$ Google-hauilla komparaatiomuotojen -sti-muotoja löytyy runsaamminkin, niin vanhemmasta kielestä (kaunokirjallisuus, virret jne.) kuin nykykielestäkin (blogit, keskustelut jne.). Muotojen yleisyyttä on kuitenkin vaikea arvioida, koska valtavissa aineistomäärissä (Suomi24-korpus, Google-hakujen löytämä aineisto) löytyy jos jotakin, myös esimerkiksi usein toistuvia virheitä. Nämä haut osoittavat kuitenkin, että muotoja käytetään.
} 


\section{Minä olen lukenut Viisasten kiven yhteensä 12 kertaa (yhdestitoista suomeksi ja kerran}

englanniksi) (Internet 5)

6. - - samoin kun niissä tusinaan kolmestitoista mahtuvissa lehtikolumneissa joissa tuskaillaan sitä kuinka "me" suomalaiset olemme niin pahoja. (Internet 6)

Myös numeraalien kanssa -sti käyttäytyy siis kuin sijatunnus.

Tässä jaksossa on tarkasteltu -sti-muotojen sijamaisuutta. Yhteenvetona esitän seuraavaa: Morfotaktisesti -sti-tunnus käyttäytyy hyvin sijamaisesti. Merkityksen kannalta se vastaa myös sijaa. Lukuopposition puuttuminen on positionaalinen piirre: laadulla itsellään ei ole lukua, eikä -stimuodossa oleva adjektiivi liity olioon, jolla olisi luku. Epäsijamaista on typologisesti se, että -sti ei liity produktiivisesti muihin substantiiveihin kuin voimasanoihin. Fennistisessä kehyksessä sija on kuitenkin määritelty niin, että se voisi kattaa myös -sti-muodon, ja suomen kielessä adjektiivit myös taipuvat sijamuodoissa itsenäisesti ilman substantiivipääsanaa, jolloin sijan määrittely ei voikaan olla sellainen, että puhuttaisiin vain substantiivista sijassa taipuvana sanana. Lisäksi sijojen kategoria on jo nyt epäyhtenäinen. Seuraavassa jaksossa paneudun siihen, miksi -sti ei kuitenkaan ole fennistiikassa saanut sijan statusta.

\section{Miksi -sti-muotoa ei nähdä sijana?}

Edellä olen kuvannut -sti-suffiksin käyttöä ja merkitystä ja sitä, miten sitä on fennistiikassa kuvattu. Vaikka Tuomikosken (1973) ajatus -sti-suffiksin sijatunnusstatuksesta on saanut jonkin verran tunnustusta, ajatus jää silti usein vain alaviitemaininnaksi tai kuriositeetiksi. Miksi fennistiikka on ollut niin vastahankainen hyväksymään Tuomikosken ajatusta -sti-muodosta sijamuotona? Vaikka todettaisiin, että -sti-muodot eivät selvästi ole "varsinaisia" adverbeja (Sulkala 1981) tai ne nähtäisiin syntaktisesti derivoiduiksi adverbeiksi (Orpanan 1988), Tuomikosken (1973) käsitystä siitä, että kyseessä olisi todella sijamuoto, on ollut vaikeampi sulattaa, ja asia jätetään mieluummin auki kuin tunnustetaan suuntaan tai toiseen. Mutta miksi näin on? Miksi Tuomikosken (1973) toimiva ja loogisesti pätevä perustelu ei ole saanut enempää vastakaikua?

Yhtäältä syynä lienee traditio: -sti-muodot on ollut perinteistä nähdä adverbeina ja sijojen lukumäärä viitenätoista. Tradition vaikutus voi olla hyvinkin vahva. Traditio luonnollistaa tietyt ajattelutavat, jolloin niiden kyseenalaistaminen tulee vaikeaksi. Toisaalta on kuitenkin olemassa myös aito näkökantaero - kyse ei ole vain traditiosta ja sen säilyttämisen halusta tai kyvyttömyydestä kyseenalaistaa perinteistä näkemystä. Ilmeisesti moni aidosti näkee -sti-muodot adverbeina, jopa 
leksikaalisina adverbeina. ${ }^{15}$ Nähdäkseni kyseessä on todellinen näkökulmaero. Jos katsotaan -stimuotoja morfeemeittain, nimenomaan -sti-suffiksin tehtävästä käsin, -sti näyttää toimivan kuin sija. -sti-muoto asettuu vaivatta yhdeksi adjektiivinmuodoksi (tai numeraalinmuodoksi tms.) muiden joukkoon, esimerkiksi:

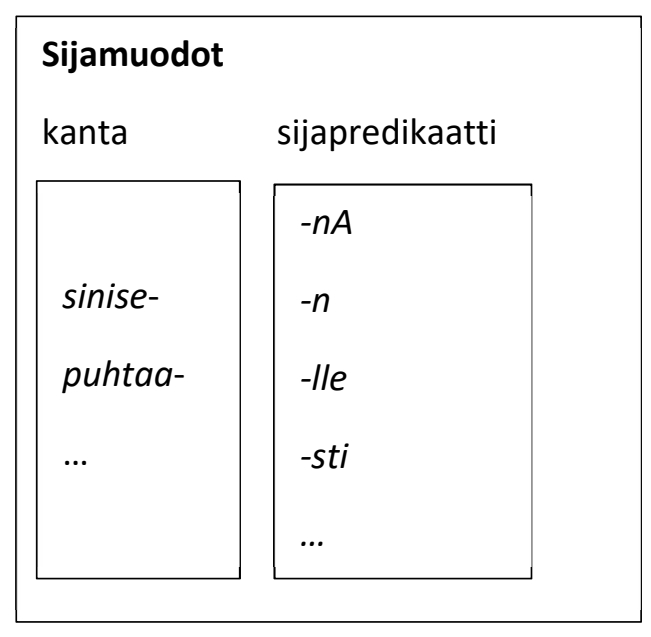

Kuvio 1: -sti-muodon näkeminen sijaparadigman osana.

Kannalla (sinise-, puhtaa-) on oma merkityksensä, sijatunnuksella (-nA, -n, -lle, -sti) omansa. Kokonaisuuden - taivutetun muodon - merkitys voidaan nähdä näiden summana. Samalla taivutussuffiksi luo kokonaisuudelle uuden valenssin, mahdollisuuden liittyä toiseen konstruktioon, jossa sillä on kognitiivisen kielentutkimuksen kuvauksen mukaisesti elaboraatiopaikka, jota ilmaus sopii työstämään (ks. Pentti Leino 1989: 179-182). Tämän näkemyksen mukaisesti kantana olevan sanan (sinise-, puhtaa-) merkitykselle tai yhdistelmän sanaluokalle ei tapahdu mitään. Yhdistelmän valenssin määrääjä on sijapredikaatti. On siis mahdollista katsoa kokonaisuuden tehtävää sijapäätteestä käsin, kuten Tuomikoskikin (1973) tekee.

Toisaalta -sti-muotoa on mahdollista katsoa semanttisena kokonaisuutena, ei kahdesta predikaatista koostuvana merkitysyhdistelmänä. Kun näin tehdään, -sti-muotoa katsotaan toisenlaisen paradigmaattisen kategorian jäsenenä. Sitä ei nähdä kompositiorakenteena vaan adjektiivista johdettuna leksikaalisena yksikkönä, jolla kokonaisuutena on uudenlainen valenssi ja merkitys. -stimuotoisen yksikön sanaluokka on adverbi ja syntaktiset tehtävät ja käytös sen mukaiset. Esimerkiksi voitaisiin hahmottaa tämänsuuntainen kategoria:

\footnotetext{
${ }^{15}$ Olen kysynyt tätä useilta kollegoiltani mutta en systemaattisen kyselyn avulla. Ne, jotka ovat olleet valmiita näkemään -sti-muodot sijataivutuksena, ovat olleet vähemmistönä.
} 


\begin{tabular}{|l|}
\hline Adjektiivikantaiset \\
johdokset \\
puhta-us > substantiivi \\
puhtaa-mpi > adjektiivi \\
puhd-istaa > verbi \\
puhd-ist-ua > verbi \\
puhtaa-sti > adverbi \\
...
\end{tabular}

Kuvio 2: -sti-muodon näkeminen johdosten joukossa.

Edelleen on mahdollista nähdä johtaminen joko leksikaalisena tai syntaktisena, mutta kielioppien perusteella -sti-muotojen muodostaminen nähdään yleensä leksikaalisena johtamisena.

Tämä toinen katsantokanta on sekin omalla tavallaan validi. Nähdäkseni Tuomikoski (1973) ei täysin ota huomioon -sti-muotojen kaksitulkintaisuutta. Sekin on täysin ymmärrettävää: kahdesta tavasta analysoida on mahdollista valita toinen.

Olen edellä tarkastellut suffiksia -sti, sen käyttöä ja merkitystä ja summannut sitä, miten suffiksi on ymmärretty fennistiikassa. Vielä on käsittelemättä viimeinen kysymys: Mikä se oikeastaan on? Voidaanko -sti siis lukea sijaksi?

Morfologisesti -sti käyttäytyy kuin sija, siitä huolimatta, että substantiivit eivät taivu -stisijassa. Päätettävä olisi varmasti, mikä on sijan kategorian määrittelyn kannalta kaikkein oleellisinta: se, että substantiivit voivat produktiivisesti taipua sijamuodossa, jolloin -sti ei ole sija, vai esimerkiksi se, että kyseessä on produktiivisesti käytettävä, morfotaktisesti sijan tavalla käyttäytyvä morfeemi, joka osoittaa kantavartalonsa tehtävän lauseessa tai lausekkeessa, jolloin -sti on sija.

Toinen kysymys on sen sijaan se, mitä saavutettaisiin -sti-muodon kutsumisella sijamuodoksi. Nimityksen valinta on luonnollisesti enemmän akateeminen kuin käytännönläheinen kysymys; -sti käyttäytyy joka tapauksessa tavallaan. Kun kuvataan sijamuotojen joukkoa kieliopissa, kyseessä on kielen käyttäytymisen teoreettinen kuvaus. Kielenkuvauksen kielioppi on artefakti, jonka luokat ovat viime kädessä luotuja, eivät luonnollisia. Voiko kaikki kielenilmiöt pakottaa luokkiin? Luokittelu on tieteellisen työn ydintä. Toisaalta on myönnettävä, että kielessä ja kielten välillä on paljon 
kategorioiden jatkumomaisuutta - kieliopin kuvaus pakkaa kuvauskohteen kenties siistimpiin paketteihin kuin mihin kuvauskohde taipuu. Eräiden rajatapausten kohdalla artefaktiksi ymmärretyn kieliopin tarjoaman kategorian päättäminen todella on hankalaa, ja -sti on yksi näistä tapauksista kenties sen pakottaminen luotuun luokkaan on epämielekästä. Se voidaan nähdä luonteeltaan kaksitulkintaisena. Lisäksi myös koko sijojen luokka on luomus, jonka olisi voinut muodostaa toisinkin - luokka ei ole yhtenäinen, kuten totesin edellä. Yhtenäisen sijojen luokan voisi jättää kokonaan muodostamattakin, jos kielen rakenteiden tarkastelussa esimerkiksi päätettäisiin lähteä ylemmän tason konstruktioista (ks. Croft 2001, 2005). Tällöin sananmuotoja ei tarkasteltaisi välttämättä ollenkaan paradigmana tai paradigma saattaisi muodostua toisin. Toisessa tutkimuksessa olenkin lähtenyt kuvaamaan -sti-muotojen pääfunktioita ("tavan", multiplikatiivisuuden tai määrän ilmaiseminen) konstruktiokieliopin keinoin: suffiksi muodostaa tietynlaisen sanan kanssa konstruktion, joka ilmentää tietynlaista merkitystä ja joka liittyy lauseyhteyteen tietyllä tavalla. Tällaisessa kuvauksessa ei ole välttämätöntä ottaa lainkaan kantaa suffiksin luonteeseen. ${ }^{16}$

Tässä kirjoituksessa olen kuitenkin lähtenyt tarkastelemaan -sti-muodon asemaa fennistisen parinteen kontekstissa. Tässä perinteessä kallistun Tuomikosken (1973) kannalle siinä, että produktiivisesti tuotetut -sti-muodot olisi luettava adjektiivinmuotoihin (ja numeraalin- tms.). Niiden näkeminen nimenomaan adjektiiveina muiden adjektiivinmuotojen joukossa paljastaa jotain myös adjektiivien käytöstä ja merkityksestä. -sti-muotojen näkeminen adjektiivien produktiivisina sijamuotoina vahvistaa myös adjektiivien asemaa sanaluokkana, mikä on typologisesti oleellista: suomessa olisikin sellainen itsenäinen, nimenomaan adjektiivien semanttinen funktio, "tapa" (yläkäsitteenä), jota ilmaistaan sijatunnuksen avulla. Tässä on esimerkki siitä, miksi kieliopin olioiden kategorisoiminen on merkittävää. Jos tutkimme -sti-muotoja perusmuotoisina lekseemeinä (adverbeina), emme löydä samoja asioita kuin jos tutkisimme niitä taivutettuina sanoina, adjektiivinmuotoina.

Koska kielenkuvaus on väistämättä luokitteleva, yleistävä ja kategorisoiva abstraktio, siinä on ikään kuin sisäänrakennettuna tietty keinotekoisuuden, "vääryyden" elementti. ${ }^{17}$ Kuitenkin ihanteena kielenkuvauksessa on kuvauksen yhtenäisyys ja luotettavuus. Kielenkuvauksen onnistuneisuutta on arvioitava esimerkiksi sen sisäisen johdonmukaisuuden perusteella. Välillä on siis hyödyllistä pohtia sitä, miten ja millä perustein kategoriat jaetaan ja nimetään ja millä perusteilla niiden jäsenyys

\footnotetext{
${ }^{16}$ Artikkelissa "The Finnish -sti forms: derivation or case inflection?" teoksessa Jaakola, Minna \& Tiina Onikki-Rantajääskö (toim.), Cognitive linguistic perspectives on Finnish case system.

${ }^{17}$ Kiitän Markus Hamusta tästä huomiosta!
} 
myönnetään. Jos ihanteena pidetään kielenkuvauksen sisäistä johdonmukaisuutta, olisi -sti-muoto mielestäni laskettava sijamuodoksi. Samaa ratkaisua puoltaa se, että näin tekemällä saataisiin parempi ja todellisempi kuva adjektiiveista ja adjektiivien käytöstä.

Aineistolähteet:

Internet 1 = https://www.mtvuutiset.fi/artikkeli/polonium-tappaa-tuskallisesti-myrkytys-on-kuinsyovan-loppuvaihe/5702294\#gs.x8atxh (21.3.2018).

Internet 2 = https://www.modernistikodikas.fi/sisustus/talviterassi-taydellisen-kaunis-aamu/ (21.3.2018).

Internet $3=$ https://www.vauva.fi/keskustelu/727062/ketju/minulla_olisi_yksi_kysymys (21.3.2018) Internet 4 = https://pojanblogi.blogspot.com/2015/07/ulkoasu-kriisi.html (21.3.2018).

Internet 5 = https://www.finfanfun.fi/index.php?topic=733.0 (21.3.2018).

Internet $6=$ https://hommaforum.org/index.php?topic $=108907.1350$ (21.3.2018).

Suomi24 = Aller Media Oy (2014). Suomi 24 virkkeet -korpus (2016H2) [tekstikorpus].

Kielipankki. Saatavilla http://urn.fi/urn:nbn:fi:lb-2017021505.

Kielipankki $=$ CSC - Tieteen tietotekniikan keskus (1998). Suomen kielen tekstikokoelman HelsinkiKorp-versio [tekstikorpus]. Kielipankki. Saatavilla http://urn.fi/urn:nbn:fi:lb-2016050207.

Lähteet:

AHLMAN, ERIK 1933: Adverbeista. - Virittäjä 37 s. 137-159.

Alho, IRJA - KAuPPINEN, ANNELi 2008: Käyttökielioppi. Helsinki: Suomalaisen Kirjallisuuden Seura.

Blake, Barry J. 2001: Case. Second Edition. Cambridge: Cambridge University Press.

CROFT, WILLIAM 2001: Radical construction grammar: syntactic theory in typological perspective. Oxford: Oxford University Press. 
2005: Logical and typological arguments for Radical Construction Grammar. - Mirjam Fried \& Jan-Ola Östman (toim.), Construction grammar in a cross-language perspective s. 273315. Philadelphia, PA: John Benjamins Publishing.

DiXON, R. M. W. 2004: Adjective classes in typological perspective. - R. M. W. Dixon \& Alexandra Y. Aikhenvald (toim.), Adjective classes: a cross-linguistic typology s. 1-49. Oxford: Oxford University Press.

HAKUlinen, Auli - KARlsson, Fred 1979: Nykysuomen lauseoppia. Helsinki: Suomalaisen Kirjallisuuden Seura.

HAMUNEN, MARKUS 2019: Tavattomat infinitivivit. Eräiden myötätapahtumisen infinitiivirakenteiden konstruktiokielioppia suomen murteissa. Väitöskirjatutkimus. Helsingin yliopisto. http://urn.fi/URN:ISBN:978-951-51-5203-9.

HASPELMATH, MARTIN 1996: Word-class-changing inflection and morphological theory. - Geert Booij \& Jaap van Marle (toim.), Yearbook of Morphology 1995 s. 43-66. Kluwer Academic Publishers.

HuUmo, TUOMAS 1997: Lokatiivit lauseen semanttisessa tulkinnassa. Ajan, omistajan, paikan ja tilan adverbiaalien keskinäiset suhteet suomen kielessä. Turun yliopiston suomalaisen ja yleisen kielitieteen laitoksen julkaisuja 55.

IgGeSEn, Oliver A. 2013: Number of Cases. - Matthew S. Dryer \& Martin Haspelmath (toim.), The World Atlas of Language Structures Online. Leipzig: Max Planck Institute for Evolutionary Anthropology. http://wals.info/chapter/49 (23.7.2019).

ITKONEN, TERHO 1986: R. Tuomikoski 75-vuotias. - Virittäjä 90 s. 77-79.

ISK = HAKULINEN, AULI - VILKUNA, MARIA - KORHONEN, RIITTA - KoIVISTO, VESA - HEINONEN, TARJA RiITTA - Alho, IRJA 2004: Iso suomen kielioppi. Helsinki: Suomalaisen Kirjallisuuden Seura.

JAAKOLA, MinNa 2004: Suomen genetiivi. Helsinki: Suomalaisen Kirjallisuuden seura.

JÄÄSKELÄINEN, ANNI 2018: Ajallisuus, toistuvuus ja toistuvuuden tulkinnat. Esitelmä XLV

Kielitieteen päivät 2018, Helsinki, 7.5.-9.5.2018. 
JÄÄSKELÄINEN, ANNI - HAMUNEN, MARKUS 2011: Adjuncts of manner seen in terms of valence and elaborations sites - the case of Finnish sti-adverbs. Esitelmä International Cognitive Linguistics Conference ICLC 11, Xi'an, Kiina, 11.-17.7.2011.

KARLSSON, Fred 1999: Finnish: An essential grammar. New edition. London: Routledge.

KORHONEN, RitTtA - MAAMIES, SARI (toim.) 2015: Kielitoimiston kielioppiopas. Helsinki: Kotimaisten kielten keskus.

KITTILÄ, SEPPO - VÄSTI, KATJA - YLIKOSKI, JUSSI 2011: Introduction to case, animacy and semantic roles. - Seppo Kittilä, Katja Västi \& Jussi Ylikoski (toim.), Case, animacy and semantic roles. Typological Studies in Language Vol 99 s. 1-26. Amsterdam: John Benjamins Publishing Company

LANGACKER, RoNALD W. 2008: Cognitive grammar. A basic introduction. Oxford: Oxford University Press.

LEINO, JAAKKO 2003: Antaa sen muuttua. Suomen kielen permissiivirakenne ja sen kehitys. Helsinki: Suomalaisen Kirjallisuuden Seura.

LEINO, PENTTI 1989: Paikallissijat ja suhdesääntö: kognitiivisen kieliopin näkökulma. - Virittäjä 93 s. $161-219$.

_ 1993: Polysemia - kielen moniselitteisyys. Suomen kielen kognitiivista kielioppia 1. Kieli 7. Helsingin yliopiston suomen kielen laitos.

LEINO, PIRKKO 1999: Suomen kielioppi. 5., uusittu painos. Helsinki: Otava.

LESKINEN, JUHA 1990: Suomen kielen inkongruentit instruktiivirakenteet ja niiden tausta. Helsinki: Suomalaisen Kirjallisuuden Seura.

NS = Nykysuomen sanakirja, niteet 1-3, 1966, lyhentämätön kansanpainos. Päätoimittaja Matti Sadeniemi. Valtion toimeksiannosta teettänyt Suomalaisen kirjallisuuden seura. Helsinki: WSOY.

ORPANA, TERTTU 1988: Kuvaus vai kommentti: tutkimus suomen kielen adjektiiviadverbien semanttisesta tulkinnasta. Opera fennistica \& linguistica 2. Tampereen yliopiston suomen kielen ja yleisen kielitieteen laitos.

PAJUNEN, ANNELi 1994: Adjektiivi-kategorian universaaliudesta. -Virittäjä 98 s. 513-542.

PentTILÄ, AARni 1957: Suomen kielioppi. Porvoo: WSOY. 
Portero Muñoz, Carmen - García Velasco, Daniel 2018: A new proposal for the distinction between lexical and syntactic derivation in Functional Discourse Grammar. - Word Structure 11.1 s. 95-117. https://doi.org/10.3366/word.2018.0117

PUlKKInEN, PAAVO 1994: Helpoiten ja vaikeiten. - Virittäjä 98 s. 330-333.

SetÄlä, E. N.- Nieminen, KAARlo - OJAJÄrVI, Aulis 1974 [1964]: Suomen kielen oppikirja. 24. painos. Helsinki: Otava.

SÄRKKÄ, TAUNO 1969: Itämerensuomalaisten kielten eksessiivi. Helsinki: Suomalaisen Kirjallisuuden Seura.

SiRO, PAAVO 1964: Suomen kielen lauseoppi. Helsinki: Tietosanakirja Oy.

SulKala, Helena 1981: Suomen kielen ajan adverbien semantiikkaa. Acta Universitatis Ouluensis Series B Humaniora No. 8 Philologica No. 3. Oulun yliopisto.

Tieteen termipankki 23.07.2019: Kielitiede:sija. https://tieteentermipankki.fi/wiki/Kielitiede:sija.

Tieteen termipankki 23.07.2019: Kielitiede:syntaktinen derivaatio.

https://tieteentermipankki.fi/wiki/Kielitiede:syntaktinen derivaatio.

TUOMIKOSKI, Risto 1973: Adjektiivin ja adverbin erosta. - Virittäjä 77 s. 199-213.

VILKUNA, MARIA 1996: Suomen lauseopin perusteet. Kotimaisten kielten tutkimuskeskuksen julkaisuja 90. Helsinki: Edita.

YLIKOSKI, JUSSI 2018: Prolatiivi ja instrumentaali: suomen -(i)tse ja -teitse kieliopin ja leksikon rajamailla. - Sananjalka 60 s. 7-27.

Kirjoittaja on tutkijatohtori Helsingin yliopistossa. 